\title{
Přerušovaná spojení. Budování infrastrukturního zázemí v jedné východoslovenské romské osadě 1
}

\author{
Disconnecting Connections. On the Building of the Infrastructure \\ in an Eastern Slovakian Roma Settlement
}

Tomáš Kobes

\begin{abstract}
The article deals with the implementation of the basic infrastructure into the area of an Eastern Slovakian Roma settlement. The infrastructure is conceptualized as an assemblages of material objects, practices and knowledge organizing the existing social relationships, and contributing to the exclusion and marginalization of Roma people. Based on the fieldwork, author discusses the consequences of the infrastructural building (public water supply system, public lighting and electric network) and how do they contribute to the forms of disconnections creating the differences between local majority and people who live in the described Roma settlement.
\end{abstract}

KEY WORDS infrastructure, marginalization, exclusion, Roma settlements

\section{Úvod}

Když jsem na podzim roku 1999 poprvé navštívil osadu, nebyla zde zavedena žádná elektrická sít' a lidé zde byli bez zdroje pitné vody. O šest let později jsem při jednom ze svých zimních pobytů onemocněl. Trpěl jsem průjmy a vysokými horečkami způsobenými zkaženým masem. Pro obyvatele osady to nebylo nic nového. Občas se to stávalo také jim a jejich dětem. V nedalekém polském městečku kupovali v objemných kartonech laciné zmražené kuřecí maso, které pak bylo během převozu rozmraženo a znovu zmraženo, jak ho uskladňovali ve svých nových lednicích a mrazácích. Ledničky, mrazáky, stejně jako televize, satelity a mobilní telefony byly na osadě novým fenoménem, který byl umožněn zavedením elektrické sítě. Proto mi mohli moji domácí vodu na čaj a kafe během mé nemoci převařovat v rychlovarné konvici. Rychlovarná konvice se stala velmi důležitým nástrojem kontroly kvality vody. Navzdory změnám spojeným se zavedením elektrické sítě zdroj vody zůstal stejný a byl předmětem neustálých sporů o její kvalitu. De facto byla výrazem jejich bídného života neustále srovnávaného se životní úrovní majoritních obyvatel obce. Jak podotkl Laco, můj kamarád a domácí: „Kulturni je ten, kdo má koupelnu s horkou vodou a splachovací záchod." Věta asi nejlépe vyjadřuje, jak sami sobě obyvatelé osady v neustálém srovnávání

Sociální studia / Social Studies 3/2016. S. 101-119. ISSN 1214-813X.

1 Tato studie byla zpracována s podporou grantu Institucionální podpora na dlouhodobý koncepční rozvoj výzkumné organizace - KSS FF ZČU v Plzni. 
s infrastrukturní dostupností a kvalitou života rozumí. Infrastrukturní zázemí jimi bylo vnímáno jako nedostatečné a jejich pocit méněcennosti, zaostalosti a frustrace byl umocňovaný vzrůstajícími hádkami kvůli placení účtů za elektřinu.

Osada se nachází v Busovské vrchovině v blízkosti slovensko-polských hranic. Mezi roky 1999-2012 se počet obyvatel pohyboval mezi 140 až 160 obyvateli. V současné době zde žije kolem 200 obyvatel, kteří vždy nějakým způsobem referují k místní fajtě. Ta zde vystupuje nejen jako kognatická descendenční skupina referující k zakladatelskému páru, ale je také synonymem způsobu života, který je pro tuto osadu typický a který se v detailech liší od způsobu života v ostatních osadách. Do takto vymezované fajty se člověk může narodit nebo se jejím členem či členkou může stát na základě sdíleného způsobu života obyvatel dané osady. Způsob života s sebou nese morální podtext určující, co je správné a co nesprávné, ve svém důsledku vymezující rozdíl mezi těmi, kteří žijí v př́islušné osadě, a těmi ostatními, včetně jejich majoritních protějšků, obyvateli osady označovaných obvykle jako gádžové (srov. Kobes 2010). Být Romem či členem určité fajty staví obyvatele př́íslušné osady do pozice morální nadřazenosti nad jejich majoritními sousedy a obyvateli okolních romských osad. Ta je však neustále zpochybňována neexistencí funkční infrastruktury, jež by umožnila obyvatelům osady vést život srovnatelný s gádžovskými standardy.

Zatímco pro většinu obyvatel Slovenska je př́stup k základní infrastruktuře, jako jsou voda a elektřina, samozřejmostí, pro obyvatele osad je tato základní vybavenost dostupná problematickým způsobem. ${ }^{2}$ Podle Správy o životných podmienkach rómskych domácností na Slovensku měla v roce 2010 vodu z veřejného vodovodu zavedena méně než polovina romských domácností a čtvrtina romských domácností byla odkázána na zdroje vody mimo vlastní obydlí. K nejvíce problematickým pak patří voda z pramene či potoka s nevyhovující kvalitou vody (5,7\% romských domácností). Co se týče elektrické energie, je situace v porovnání s dostupností zdravotně nezávadné vody lepší. Do $92 \%$ těchto lokalit je zavedena elektrická sít', z toho $76,5 \%$ domácností je připojena po dobu celého roku. Přerušované prripojení se týkalo $18,3 \%$ domácností, přičemž největší podíl přerušovaného elektrického připojení se týkal sociálně vyloučených lokalit či osad $(41,8 \%)$ z důvodu neschopnosti platit účty za elektřinu (Správa 2010: 67, 71).

Již jen tato data naznačují jedno z možných vysvětlení diverzifikace infrastrukturního připojení, které je dáváno do úzkého vztahu k exkluzi a marginalizaci. Podle existujících textů diskutujících problematiku infrastruktur ve slovenských romských osadách není jejich nedostatečná infrastrukturní vybavenost jednoduše způsobena pozemkovým vlastnictvím nebo typem vlády, ale souvisí se širším ekonomickými a politickými zájmy (Filčák 2012) či obecněji s mocenskou asymetrií slovenských obcí a měst posilující etnické bariéry mezi majoritou a obyvateli romských osad (Škobla, Filčák 2014).

Když James Ferguson uvažuje o prohlubující se chudobě horníků v Zambii, vytváří odlišný způsob argumentace. Chudoba, marginalizace a exkluze nemusí být nutně důsledkem

2 V současné době je na Slovensku kolem 800 sociálně vyloučených lokalit, které jsou v běžném jazyce označovány převážně jako „romské osady“ (srov. Mušinka et al. 2014). Tyto lokality jsou velice často situovány v areálech s nejasnými vlastnickými vztahy typickými rozsáhlou nelegální výstavbou s nedostatečnou infrastrukturní vybaveností. 
chybějícího propojení (lack of connection), ale spíše opakovaného rozpojování (disconnection). Pro Fergusona je rozdíl mezi „být nespojen“ (unconnected) jako výchozím stavem a „být odpojen“ (disconnected) jako historickým výsledkem procesu rozpojení (disconnection) (Ferguson 1999: 238). Rostoucí dluh neplatiče přispívá k přerušení či opakovanému přerušovanému spojení, a to nejen ve smyslu odběru energie, ale také ve smyslu vyvazování jednotlivců či určitých skupin z rámců vymezujících jejich identitu a poukazujících na to, kým jsou či kým by mohli být.

Princip takových přerušovaných spojeních lze přiblížit analogicky na rozdílu mezi filiací a descendencí. V př́buzenských studiích je filiace definována jako vazba, která spojuje děti symetricky s jejich rodiči či šiřeji s otcovskými a mateřskými př́buznými. Oproti tomu descendence je vztah, jehož povaha je vymezená pravidlem definujícím spojení mezi potomkem a jeho předkem. Př́ibuzenská studia v tomto smyslu rozlišují mezi unilineárními, duolineárními, bilineárními a ne-lineárními systémy (srov. Skupnik 2010: 50-63 a Godelier 2011: 87). Výsledkem uplatnění takového pravidla je, že určité jednotlivce staví do pozice př́ibuzných a neprríbuzných osob, a přispívá tak k přerušení či rozpojení filiační vazby. Předmět výzkumu descendenčních skupin je vždy spojen s otázkou, kdo nebo co vymezuje homogenitu či sounáležitost členů určité descendenční skupiny (např. fajty) a spojuje určitého jednotlivce s ostatními členy této skupiny, nebo ho odděluje od ostatních.

Tento princip lze aplikovat na oblast infrastruktury. Infrastruktura je forma spojení a propojení vyplývající z technických a ekonomických možností jednotlivců či určitých skupin, ale také se podílející na vytváření rozdílu mezi rozvinutými a zaostalými. $V$ této perspektivě se z infrastruktury stává jeden z nástrojů či měřítko pro vymezování blízkostí a vzdáleností a mým záměrem je na základě terénních poznámek pořízených během výzkumných pobytů mezi roky 1999-2014 ukázat vzájemnou provázanost infrastruktury, lokální sociální praxe a politiky a způsobů, jak se podílí na vytváření různých forem přerušovaných spojení prohlubujících marginalizaci obyvatel sledované romské osady.

V tomto smyslu je důležitá především následující otázka: jaké jsou důsledky zavedení základní infrastruktury do areálu osady? Tento bod je podstatný, protože umožňuje zviditelnit oblasti, které jsou důležité pro způsoby vymezování identity obyvatel osady a jejich majoritních protějšků, a napomáhá nám tak zodpovědět další důležitou otázku: z jakých komponentů se skládá realita sledované romské osady a jak tyto komponenty prrispívají k vytváření lokálních vztahů či jejich rozpojovaných forem, které se podílejí nejen na marginalizaci jejích obyvatel, ale v obecné rovině také na odlišném pojetí humanity?

\section{Význam výzkumu infrastruktury}

V STS (Science and technology studies), historii vědy a technologie, stejně jako v antropologii existuje literatura zdůrazňující význam výzkumu infrastruktur (např. Bijker, Hughes, Pinch 1987; Bowker, Star 1999; Star 1999; Edwards, Bowker, Jackson, Williams 2009; Harvey, Knox 2012). Infrastruktura zde není jednoduše koncipovaná jako forma technického spojení, ale spíše jako komplex heterogenních asambláží materiálních objektů, praxí a vědění ovlivňujících život lidí, kteří každodenně využívají jistý typ infrastruktur. Infrastruktury svou podstatou jsou jedním z aktivních organizačních principů či měřítkem existujících sociální 
vztahů (srov. Star 1999; Strathern 1995: 25-27), které umožňují ve vztahu k záměru textu zviditelnit vzájemnou provázanost různých forem vědění, sociálních praxí a lokálních politik na úrovni samosprávy a romské osady.

Brian Larkin (2013) v přehledové stati o významu infrastruktur v antropologickém výzkumu vymezuje infrastrukturu jako podloží, na jehož základě jiné objekty jednají a v tomto smyslu by se výzkum infrastruktur měl zaměřit na způsoby utváření věcí a vědění zprostředkovávající různé formy interakcí. Podle Larkina vztahy mezi těmito doménami vytvářejí možnost identifikovat jejich ontologie, které jsou specifické nepředvídatelnou změnou (Larkin 2013: 329). V tomto smyslu Casper Bruun Jensen a Atsuro Morita poznamenali, že předmět změny není jen komponentem existujících infrastruktur, ale také formou politiky, společnosti či obecněji komplexního životního prostředí (environment) zahrnující rozdíly mezi přirodou a společností, které jsou důsledkem existujících infrastrukturních uspořádání (Jensen and Morita 2015: 83).

Tyto principy lze aplikovat při popisu zavádění infrastruktury do $\mathrm{v}$ úvodu zmíněné osady. Podle Mary Douglas (1970) jedním ze základních organizačních principů každé společnosti je rozlišení mezi čistým a nečistým. $\mathrm{V}$ prípadě obyvatel romských osad logika této kategorizace může být odvozena od zkušenosti s lidskou tělesností. Tělo je měřítkem konstituujícím rozdíl mezi doménami uvnitř a vně. Uvnitř je sférou, jež by měla být chráněna před vším, co může tělo uvnitř znečistit a přivodit tělu nemoc podobně, jako když jsem snědl zkažené kuřecí maso. Proto by tato oblast měla být neustále udržována v čistotě. Zároveň rozdíl mezi těmito doménami podmiňuje logiku transformace jednotlivých prvků reality. Vše, co vychází z těla, tedy ze sféry uvnitř, je považováno za nečisté. Respektive, co bylo čisté, se tělesnými procesy proměnilo $\mathrm{v}$ nečisté. Tento princip se promítá $\mathrm{i}$ do prostorového vnímání a vymezování sociálních vztahů. Hranice uvnitř je vymezena prostorem osady, v němž se odehrává sociální život jejích obyvatel. Jakýkoliv nový afinní vztah spojující členy dvou rodin, ale také dvou osad, je ohrožením lokálních sociálních vztahů, a z toho důvodu jakýkoliv nový obyvatel na základě uzavřeného partnerství musí být vystaven zvýšené sociální kontrole. Podobně jakákoliv infrastruktura je spojnicí sfér uvnitř a vně prostoru dané osady. Co se jeví ve vztahu $\mathrm{k}$ infrastruktuře na úrovni majoritní obce jako neproblematické a vysoce funkční, je v prípadě obyvatel osady velmi problematickým výstupem konfliktů a složitých vyjednávání sledujících jeden hlavní cíl - zlepšit kvalitu života v rámci osady (domény uvnitř), a získat tak kontrolu nad svým lidstvím.

Podle Daniela Millera (2005) lze mezi materialitou a lidskostí klást rovnítko. Materialita je jedním ze způsobů organizace sociálních vztahů, včetně způsobů vymezení a utváření humanity. Pokud lze chudobu definovat jako neschopnost seberealizace $\mathrm{v}$ důsledku nedostatečného materiálního zabezpečení, potom materialita a její infrastrukturní podmínky př̀dstavují relevantní předmět antropologického zájmu, který souvisí s klasickými antropologickými otázkami, co znamená být člověkem a jaká kritéria se podílejí na vymezení lidskosti (Miller 2005: 1-2).

Infrastruktura je v tomto smyslu důležitým nástrojem pro vymezení identity. Je podstatným prostředkem stávání se (becoming, becoming with) (srov. Deleuze a Guattari 2010: 262-349 a Haraway 2008), jenž se spolupodílí na vymezení identity, sebeporozumění a porozumění druhým. Svou podstatou je tak infrastruktura relační soustavou, která poskytuje 
možnost pro zachycení utváření homogenity a různých forem diferencí. Je jedním ze zprostředkovatelů vymezujících identitu a vztahy mezi těmito zprostředkovateli jsou vzájemnými měrítky, které jsou vždy ve vztahu $\mathrm{k}$ určité činnosti, které jsou určující pro různé formy spojení a rozpojení. Pro postižení vztahu měřítka, činnosti a možných spojení či rozpojení je popis zavedení infrastruktury do romské osady strukturován následujícím způsobem. Nejprve představím vznik osady a způsob, jakým se prostorová vzdálenost podílí na rozdílu mezi našimi a cizími Romy, včetně percepce prostoru osady především na straně jejích obyvatel. V další části popíši zavedení veřejného vodovodu, který pro obyvatele osady představuje dlouhodobé zdravotní riziko. To bylo eliminováno až zavedením veřejného osvětlení a následným nelegálním rozvodem elektrické sítě. Na jeho základě je možné ukázat, jak se lidé z osady a jejich majoritní sousedé vzájemně konceptualizují a jak obyvatelé osady získali pod kontrolu své zdraví především prostřednictvím systematického využívání rychlovarných konvic a žárovek. Nicméně nelegální rozvod pro obecní úřad představoval významný ekonomický problém, který se snažil vyřešit zavedením legální elektrické sítě. Realizace tohoto záměru proběhla ve dvou problematických krocích, které vedly k dezintegraci lokální fajty a ve svém důsledku i k dezintegraci majoritních obyvatel obce. Poslední část se proto snaží přibližit, jak výstavba infrastruktury ovlivnila lokální politiku.

\section{Žít na kostech mrtvých zvî̃at}

I když podle archivních materiálů, především matričních záznamů, lze doložit, že Romové v obci žili již před rokem 1920, je vznik romské osady v její současné lokalitě nejasný. Majoritní pamětníci o této události nechtějí mluvit. Zpravidla se vymlouvají, že si na to nepamatují, nebo se snaží zdůrazňovat, že v současné lokalitě žili odedávna. Stejně nemožné je rekonstruovat vznik osady na základě obecní kroniky. Kronika ze 40. až 60. let 20. století není dostupná. Nikoliv že by nebyla pro toto období vedena, ale protože se někdy v průběhu 80. let ztratila. Pouze na základě rozhovoru s kronikářkou, která vedla kroniku pro obec před rokem 1999 a která v obci již nežije, je možné situovat vznik osady do 50. let 20. století. Pravděpodobně zde existovala snaha využít možnosti pracovních pobídek do českého pohraničí, nicméně vysídlení místní romské rodiny do Čech se v této obci nepodařilo a výsledkem bylo pouze vystěhování zakladatelského páru z katastru obce do současného areálu osady, který byl v minulosti využíván místními sedláky jako hřbitov uhynulých hospodářských zvířat (viz Obrázek 1). ${ }^{3}$

3 K takovému vysvětlení mne vede př́ípad zániku romského osídlení v sousední obci. I zde je možné přitomnost romských obyvatel vysledovat před rok 1920. Nicméně podle pamětníků během 50 . let 20. století tito Romové odešli za prací do Čech. To je pravda jen částečně. Místní jsou velmi hrdí na to, že v obci nemají již žádné Romy a za odstrašující př́íklad, jak mohla jejich obec dopadnout, považují obec mého výzkumu. Podle vyprávění místního starosty je veřejným tajemstvím, jak Romové z obce odešli. Využili možnosti pracovních pobídek v českém pohraničí. Po určité době se však do své rodné obce vrátili a $\mathrm{z}$ obavy o jejich trvalou přítomnost $\mathrm{v}$ obci jim někteří horliví členové majority jejich staré domy zbořili. 
Obrázek 1: Vysídlení zakladatelského páru z areálu obce do prostoru současné osady

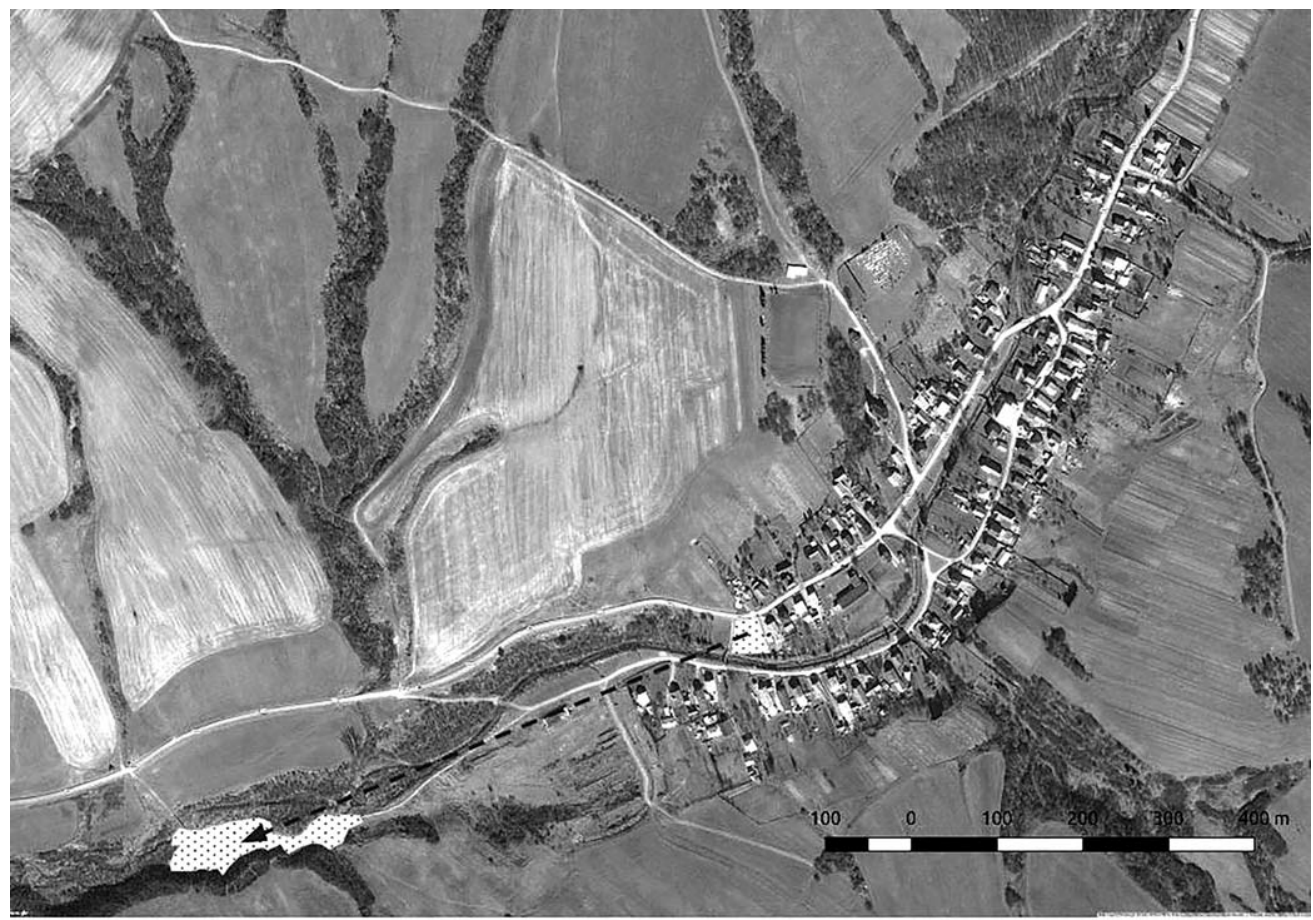

Dnes v tomto areálu žije okolo dvou set lidí, kteří jsou kategorizováni členy majority jako Romové nebo Cigáni, a přesídlení je možné chápat jako první krok rozpojení. Zakládající pár osady byl ještě klasifikován majoritou jako „naši Romové/Cigáni“،, kteří se živili především pomocnými pracemi v zemědělství a drobnou kovářskou prací. Jejich potomci, kteří dnes tvoří většinu obyvatel osady a tvoří zhruba $40 \%$ podíl na celkovém počtu obyvatel obce (v obci v současné době žije 517 obyvatel), jsou majoritou popisovaní jako „cizí Romové” (viz Obrázek 2).

Obrázek 2: Zakladatelský pár a počet členů v jednotlivých descedenčních skupinách

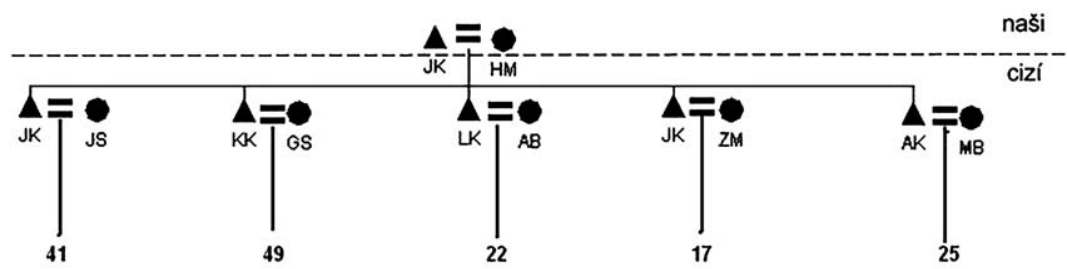

Prostor, ve kterém tito lidé žijí, však nepopisují termínem gav - výraz pro obec v romském jazyce -, ale prostřednictvím takových kategorií, jako jsou vatrisko, taboris či 
nejčastěji osada, vyjadřujících spíše určitou dočasnost nebo nepatřičnost místa než skutečnou vesnici. Už jen tento rozdíl v pojmenování naznačuje, že se jejich životy odehrávají v místě, které není srovnatelné se životními standardy majority. Obecně je prostor osady vnímán jejími rezidenty velmi nelibě. Při každém novém výkopu do země nacházejí kosti zviŕăat. Takové situace jsou velmi ponižující už jen proto, že lidé by se podle nich měli jak od mrtvých lidí, tak mrtvých zvířat držet dál. Místo je jimi vnímáno jako nečisté a nepatřičné k životu. Situaci umocňuje skutečnost, že prostor osady je z větši části situován do koryta přilehlého potoka a osada je během jarních a letních povodní ohrožena rizikem zaplavení. V minulosti se to stalo několikrát po sobě, naposledy v roce 2010 (před tím v roce 2000,2001$)$. Možné přestěhování obyvatel osady do vhodnější lokality či zpět do areálu obce je však velké téma, které ovlivňuje politickou situaci v obci. V roce 1998 byl takový projekt přestěhování obyvatel do nové lokality s vhodnou základní infrastrukturou zastaven vlivnými členy majority (především to byli majitelé pozemků, které měly být vykoupeny pro budoucí rezidenční jednotky). Z původního projektu setrval na úrovni tehdejších představitelů obce pouze příslib zavedení elektrické sítě a veřejného vodovodu, z kterého se po zrušení možného přesídlení stal pro obyvatele osady jediný nástroj nabízející naději na zlepšení životních podmínek v prostoru osady.

\section{Zavedení veřejného vodovodu}

Jedním z hlavních problémů osady je prístup k nezávadnému zdroji pitné vody. Bezprostředně poté, co jsem začal na osadě bydlet, mě v úvodu zmíněný Laco nutil $\mathrm{k}$ opakovanému fotografování jejich zdroje vody. Byla jím betonová skruž obklopená odpadky, do níž vtékal slabý pramen z úzké trubky. Druhý př́rodní pramen na opačném konci osady byl podobný a z hlediska kvality vody také zcela nevyhovující. Regionálny úrad verejného zdravotníctva zde realizoval několik rozborů vody a opakovaně upozorňoval na nevyhovující podmínky v dostupnosti a kvalitě pitné vody ve zdejší osadě. Pod rostoucí kritikou nad dlouhodobou neschopností zajistit zdravotně nezávadnou vodu pro obyvatele osady se obecní zastupitelstvo rozhodlo zavést do areálu osady veřejný vodovod. Nejedná se však o prodloužení veřejného vodovodu rozvedeného $\mathrm{v}$ areálu majoritní obce, ale o vytvoření paralelního rozvodu vody, prostřednictvím kterého byla spojena asi 200 metrů od osady vzdálená zásobárna vody $\mathrm{s}$ jediným veřejným vodním stojanem. Voda teče do areálu osady samospádem a pro obyvatele osady to měl být dostatečný a kvalitní zdroj pitné vody. Pro ně však začal být problematický. Předně, nechápali, proč obec neprodloužila stávající vodovod z majoritní obce do prostoru osady. Postupně mezi nimi začal převládat názor, že obecní zastupitelstvo peníze na výstavbu vodovodu zpronevěrilo a na místo toho postavilo levnou variantu vodovodu svádějícího vodu z rezervoáru, který byl původně určen jako zdroj vody pro hospodářská zvířata $\mathrm{v}$ bývalém zemědělském družstvu. Obyvatelé osady zavedení vodovodu dávají za př́klad toho, jak na ně nahlíží majoritní obyvatelstvo. Pro gádže - majoritu - nejsou lidskými bytostmi, ale spíše zviŕaty. Podle nich bych se žádný gádžo z veřejného vodovodu v osadě nenapil. Co je však v očích gádžů dobré pro dobytek, je dost dobré i pro Romy.

Vodovod je pro obyvatele osady problematický i z dalších důvodů. Rezervoár vody není nikterak chráněn a podle obyvatel osady může do vody spadnout cokoliv, včetně hadů, 
ještěrek, myší apod., které pak ve vodě hnijí. Z jejich pohledu je rezervoár nečistý a trvale ohrožuje jejich zdraví. Představa, že pijete vodu z nekontrolovaného zdroje, je pro obyvatele osady spojená $\mathrm{s}$ rizikem onemocnění a je to jeden ze zásadních argumentů, proč se část obyvatel osady pití vody z tohoto zdroje doposud vyhýbají nebo ho převařují. ${ }^{4}$ Po zavedení elektrické energie začaly být $\mathrm{v}$ tomto směru velmi rychle využívané rychlovarné konvice. Elektřina se tak stala jedním ze základních nástrojů, jak předcházet zdravotním rizikům způsobeným špatnou kvalitou vody.

Obrázek 3: Zavedení paralelního veřejného vodovodu

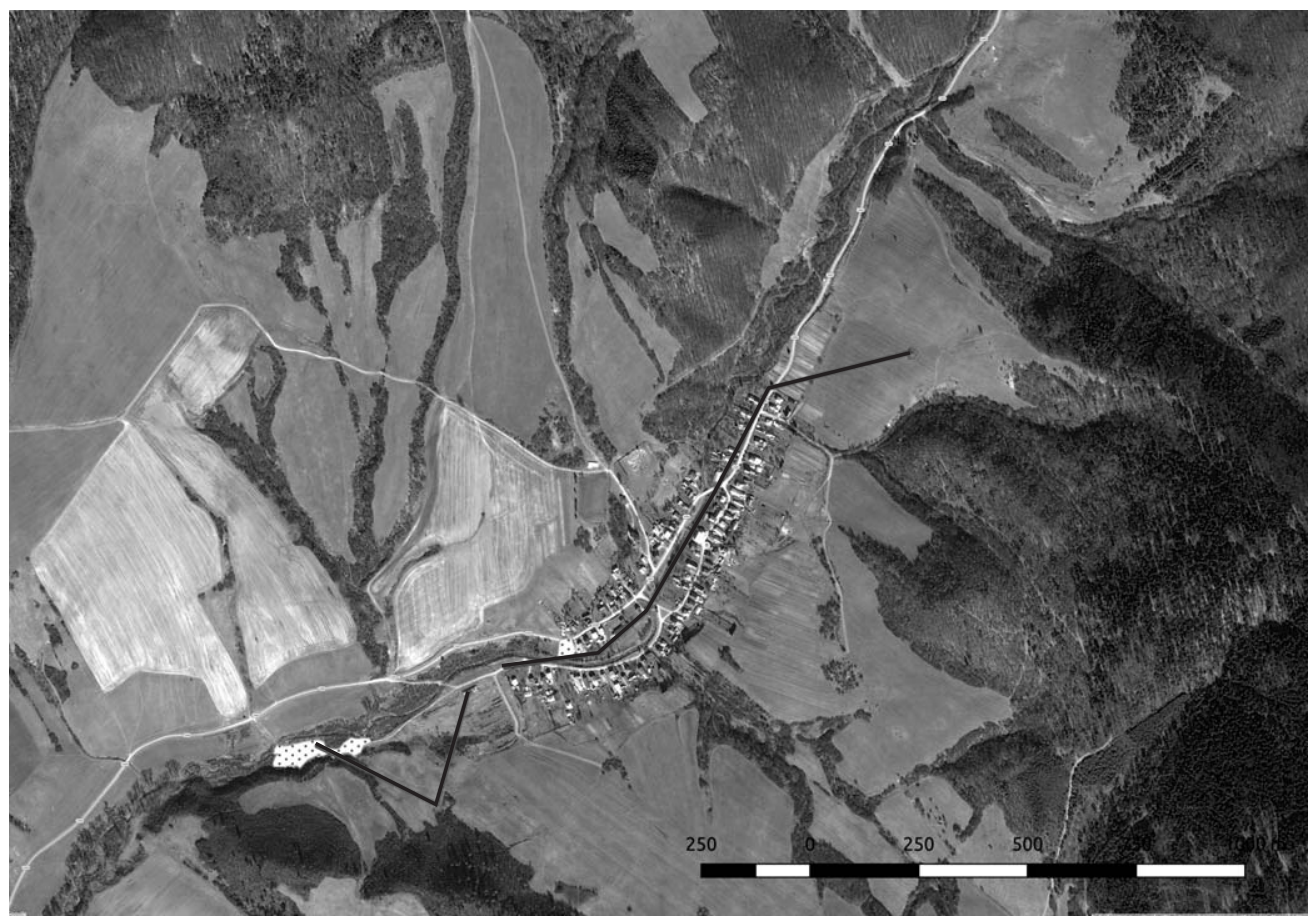

Před elektrifikací se napouštěla voda do hrnců a musela se poměrně dlouhou dobu převařovat na kamnech. Posléze se hrnec musel něčím zakrýt a držet pod kontrolou, aby do něho nepadaly mouchy či jiná špína. Mnohokrát se stalo, že pokud hrnec, napríklad z důvodu opuštění domácnosti kvůli neodkladným věcem, zůstal delší dobu bez kontroly a k převařené vodě mohl mít př́stup prakticky kdokoliv, voda $\mathrm{z}$ něho byla jednoduše vylita a celý proces bylo nutné opakovat. Rychlovarné konvice tento proces zkrátily a díky nim lidé v osadě získali efektivní kontrolu nad kvalitou vody a svým zdravím.

$4 \quad$ Alternativou je kupování vody v PET láhvích. To je však v kontextu zadlužování velmi nákladná záležitost a nejchudší obyvatelé osady se této možnosti postupně vzdali nebo ji využívají pouze př́ležitostně. 
Postup obecního úřadu při zavedení veřejného vodovodu však nebyl př́liš transparentní. Před rokem 2002 obecní zastupitelstvo odmítalo prodloužení stávajícího obecního vodovodu jako finančně nákladnou záležitost, a proto zvolilo alternativní strategii s propojením rezervoáru vody nad bývalým areálem hospodářského dvora. Problém je v tom, že oficiálně tento vodovod existuje od roku 2007, kdy na něho čerpal dotaci 70000 slovenských korun od tehdejš́ho Úradu splnomocnenkyne vlády SR pre rómske komunity, nicméně reálně existoval již v roce 2002 a pro obyvatele romské osady tato skutečnost naznačuje, že obecní úřad při zavádění vodovodu do areálu osady zpronevěřil veřejné peníze, a zároveň ukazuje způsoby, jak se členové obecního zastupitelstva obohacují na jejich úkor. Jako důkaz používají obecním úřadem vymezený speciální tarif za spotřebu vody, komunálního odpadu a daně z nemovitosti, v němž byl každé rezidenční jednotce vypočtený tarif za spotřebu vody pro jednotlivá čtvrtletí (viz Tabulka 1). Způsob výpočtu je nejasný. V zásadě je navázaný na počet obyvatel v př́slušné rezidenční jednotce. Sami obyvatelé popisovali výměr ceny za vodu na straně starosty jako směšnou záležitost, kdy starosta stál s vědrem u kohoutku a stopkami měřil, za jak dlouho se natočí do vědra 10 litrů vody. $Z$ toho důvodu odmítali předepsaný tarif za spotřebu vody platit a spatřovali $v$ tom jen další z gádžovských triků, jak je okrást. Toto podezření pak vzrostlo během zavádění veřejného elektrického osvětlení do areálu osady.

\section{Zavedení veřejného osvětlení}

Neexistence veřejného osvětlení $\mathrm{v}$ prostoru osady byla druhým největším problémem. Zvláště na podzim a $\mathrm{v}$ zimě byla osada od pozdního odpoledne nebo $\mathrm{v}$ brzkých ranních hodinách zahalena do tmy. Každá návštěva majoritní obce z důvodu nákupu jídla, použití veřejného telefonu pro zavolání sanitky $\mathrm{v}$ př́padech porodů nebo náhlých onemocnění nebo jen $\mathrm{v}$ př́ípadě docházení dětí do školy byla spojena s chůzí ve tmě. Pro obyvatele osady to znamenalo, že každá taková cesta představovala riziko ohrožující život a zdraví obyvatel osady, protože $\mathrm{v}$ jejich představách se ve tmě pohybují mulové - mrtví způsobující onemocnění nebo dokonce smrt.

Podobně majorita vnímala neexistenci veřejného osvětlení jako problém, ale z jiných důvodů. Tím, že areál osady byl od podzimu do jara prakticky ve tmě, majorita neměla pod kontrolou chování obyvatel osady. Tma $\mathrm{v}$ očích majority evokuje možnosti pro různé formy kriminálních činností a úzce souvisí s častou hypersexualizací obyvatel osady. V jejich představách se lidé v osadě vyznačují tendencí ke kriminální činnosti a nekontrolovatelnému sexuálnímu chování, častými incesty či blízkými př́buzenskými sňatky. ${ }^{5} \mathrm{Z}$ toho důvodu se v roce 2002 místní zastupitelstvo rozhodlo pro zavedení veřejného osvětlení do prostoru osady, které je prodloužením existujícího veřejného osvětlení majoritní části obce.

Propojení prostorů obce a osady však nebylo důsledné. Mezi severovýchodním koncem osady a jihozápadním okrajem obce vznikla cca 300 metrů dlouhá mezera, v níž nejsou umístěny sloupy veřejného osvětlení, a prostor tak během noci zůstává neosvětlený. Podle tehdejšího starosty a členů zastupitelstva byl důvod k existenci tohoto neosvětleného prostoru

V tomto smyslu je nutné dodat, že k podobné hypersexualizaci gádžů se uchylují obyvatelé osady. Různé erotické pořady a pornofilmy jsou pro obyvatele osady důkazem nemorálnosti gádžů. 
pragmatický. Pokud by bylo zavedeno veřejné osvětlení i do této sporné části, vytvořila by se tím pro obyvatele osady možnost nočních návštěv obce, kterou starosta a zastupitelstvo vnímali jako nežádoucí. Podle nich by se tím vytvořila možnost nejen pro noční krádeže, ale i pro rozšiřování prostoru osady prostřednictvím výstavby nelegálních domů, kterým chce starosta a obecní zastupitelstvo prostřednictvím nesouvislého veřejného osvětlení předejít. S rostoucím počtem obyvatel se prostor osady o cca 0,7 ha zahuštuje. Před rokem 2002 byla na straně obyvatel opakovaná tendence začít stavět nové rezidenční jednotky v areálu zaniklého zemědělského družstva. Obecní úřad této výstavbě zamezil a v podstatě je tento neosvětlený prostor hranicí, kde se dojednává prostor, kde mohou obyvatelé osady žití a kde již nikoliv.

Obrázek 4: Zavedení veřejného osvětlení a neosvětlený prostor mezi osadou a obcí

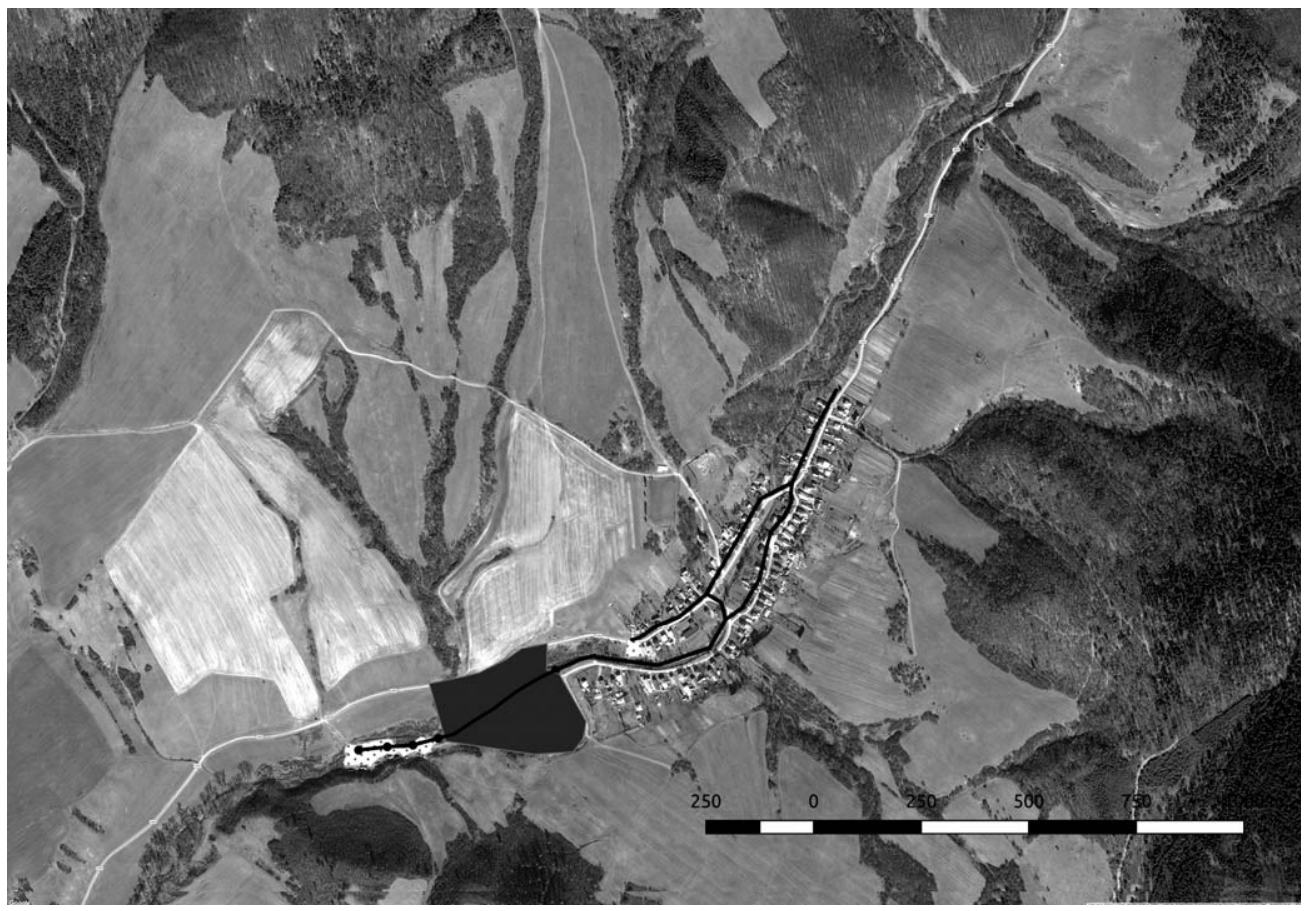

Pohled obyvatel osady na důvod neexistence souvislého veřejného osvětlení mezi prostorem osady a majoritní obce byl odlišný. Po výstavbě veřejného osvětlení se obyvatelé osady začali utvrzovat v pohledu na gádže jako zloděje. Předpokládali, že originální projekt byl plánován se souvislým osvětlením mezi osadou a majoritní obcí. Pokud však v tomto prostoru nejsou vztyčené sloupy veřejného osvětlení, celá výstavba byla o chybějící sloupy levnější a ušetřené peníze byly ukradeny členy obecního úřadu. Na př́ípadu výstavby veřejného osvětlení je zajímavá ještě jedna důležitá věc. Prakticky během půl roku byla díky existenci veřejného osvětlení v prostoru osady rozvedena ilegální elektrická sít', která jen utvrdila majoritu v jejich převládajícím pohledu na obyvatele osady jako zloděje. Na druhou stranu 
v tomto období si většina obyvatel osady začala kupovat televize a satelity, jejichž vlastnictví díky neexistence elektřiny nebylo dost dobře možné. Co je však na tomto rozvedení nelegální elektrické sítě zajímavé, že mnoho obyvatel osady mně začalo vysvětlovat, že od té doby, co byla zavedena elektrrina do prostoru osady, život $\mathrm{v}$ osadě začal být mnohem zdravější. Jeden $\mathrm{z}$ důvodu spočívá $\mathrm{v}$ tom, že začaly být $\mathrm{v}$ domácnostech velmi rychle využívány rychlovarné konvice, díky nimž obyvatelé osady získali kontrolu nad kvalitou vody.

Další důvody pro shledávání života $\mathrm{v}$ osadě mnohem zdravějším byly dávány do souvislosti s muly (mulo). Mulové je romský výraz pro mrtvé, kteří se navracejí na tento svět. Mohou mít různé podoby. Někdy je možné je potkat ve formě zviŕřete, někdy na sebe berou podobu člověka. V mnoha př́padech jsou bez tváře, ale mohou mít také podobu zemřelého člověka. Mulové mohou lidem škodit tím, že je svedou na scestí, přivodí jim onemocnění či dokonce smrt. Někdy mohou lidem dávat radu nebo je varovat (Hübschmannová 2005; Dobruská 2008). Navzdory této jejich vlastnosti, je dobré se muli̊m vyhnout. Tma je jedním z prostředí, kde je velká pravděpodobnost se s muly potkat. Zavedení veřejného osvětlení a následné rozšíření ilegální sítě tuto pravděpodobnost výrazným způsobem eliminovalo. Veřejným osvětlením byl po celou noc osvětlen prostor osady a prostřednictvím žárovek byly osvětleny jednotlivé domácnosti. Zhasínat žárovky se nevyplácí a doporučuje se je ponechat rozsvícené po celou noc. Proto lidé žijící v osadě začali v kontextu zavedení veřejného elektrického osvětlení vnímat prostor osady jako mnohem zdravější. Světlo eliminovalo možnost kontaktu s muly, a prostřednictvím žárovek v domácnostech tak získali možnost kontroly nad svým zdravím, podobně jako prostřednictvím rychlovarných konvic získali kontrolu nad kvalitou vody. ${ }^{6}$

Celodenní svícení a nákup ledniček, televizí a satelitů zvýšil skrze nelegální odběr výrazným způsobem spotřebu elektřiny, která začala neúměrně zatěžovat obecní rozpočet. Pravděpodobně zde je možné najít príícinu vzniku a vymáhání sporného sazebníku, který kromě daně z nemovitosti předepisoval čtvrtletní platbu za vodu, komunální odpad a pronájem kontejneru pro každou rezidenční jednotku v osadě. Ze zákona má na tento postup obecní úrad právo. Problém byl v tom, že $\mathrm{v}$ době, kdy byl tento sazebník vytvořen, se $\mathrm{v}$ prostoru osady žádný kontejner nenacházel. Další problém spočíval v poplatku za vodu. I v tomto př́padě má obecní úrad právo vymáhat poplatky za distribuci pitné vody veřejným vodovodem. Ale i zde je jistá obtíž. Vodovod v osadě není prodloužením obecního veřejného vodovodu, ale paralelním rozvodem, který nesplňuje parametry veřejného vodovodu. Navzdory tomu, že vodovod nedistribuoval pitnou vodu a nedisponoval žádným vodoměrem, byla ze strany obecního úřadu předepsána paušální částka $52 \mathrm{Sk}$ na osobu.

Obyvatelé osady předepsaný výměr odmítali platit právě z důvodu nesmyslného poplatku za neexistující kontejner na odpad a spornou platbu za pitnou vodu z veřejného vodovodu. V nastalém konfliktu začal obecní úřad vyhrožovat odpojením veřejného osvětlení. To však bylo spojeno s rizikem ztráty kontroly na zdravím obyvatel jak ve vztahu $\mathrm{k}$ vodě, tak ve vztahu $\mathrm{k}$ obávaným muliom a řada obyvatel pod touto hrozbou začala předepsaný čtvrtletní výměr platit a vyjednávat s neplatiči na osadě, kteří o úroveň kvality života

6 V př́padě obyvatel romských osad je zdraví a jeho konceptualizace komplexní fenomén, který jde za rámec tohoto textu. Pro bližší pochopení těchto konceptualizací viz Belák (2015 a,b). 
na osadě ztratili nebo nejevili zájem. Další problém byl ve způsobu výběru daně z nemovitosti. Obecní úráad byl $\mathrm{v}$ tomto př́padě schopen rozlišit reálný počet rezidenčních jednotek, avšak v př́ípadě rozvodu elektrické sítě uplatnil odlišnou strategii.

Tabulka 1: Výměr plateb za vodu, odpad, pronájem kontejneru a daň z nemovitosti

\begin{tabular}{|c|c|c|c|c|c|c|c|}
\hline \multirow{2}{*}{$\begin{array}{l}\text { OBYTNÁ } \\
\text { JEDNOTKA }\end{array}$} & \multirow{2}{*}{$\begin{array}{l}\text { PR̆EDPIS } \\
\text { POPLATEK } \\
\text { ZA VODU }\end{array}$} & \multirow{2}{*}{$\begin{array}{c}\text { PŘEDPIS ZA } \\
\text { KOMUNÁL. } \\
\text { ODPAD }\end{array}$} & \multirow{2}{*}{$\begin{array}{l}\text { PRONÁJEM } \\
\text { KONTEJNERU }\end{array}$} & \multirow{2}{*}{$\begin{array}{c}\text { PŘEDPIS DAŇ } \\
\text { Z NEMOVITOSTI }\end{array}$} & \multicolumn{3}{|c|}{ POPLATKY CELKEM } \\
\hline & & & & & $\begin{array}{c}\text { Do } 31.3 . \\
2002\end{array}$ & $\begin{array}{c}\text { Do } \\
30.6 .2002\end{array}$ & $\begin{array}{c}\text { Do } \\
30.9 .2002\end{array}$ \\
\hline 1 & 1248 & 960 & 30 & 36 & 802 & 736 & 736 \\
\hline 2 & 1092 & 840 & 30 & 32 & 706 & 644 & 644 \\
\hline 3 & 936 & 720 & 30 & 16 & 718 & 672 & 312 \\
\hline 4 & 1404 & 1080 & 30 & 29 & 887 & 828 & 828 \\
\hline 5 & 1560 & 1200 & 30 & 36 & 986 & 920 & 920 \\
\hline 6 & 468 & 360 & 30 & 40 & 586 & 156 & 156 \\
\hline 7 & 1248 & 960 & 30 & 55 & 821 & 736 & 736 \\
\hline 8 & 936 & 720 & 30 & 49 & 751 & 672 & 312 \\
\hline 9 & 624 & 480 & 30 & 29 & 507 & 448 & 208 \\
\hline 10 & 624 & 480 & 30 & 9 & 487 & 448 & 208 \\
\hline 11 & 624 & 480 & 30 & 15 & 493 & 448 & 208 \\
\hline 12 & 936 & 720 & 30 & 24 & 726 & 672 & 312 \\
\hline 13 & 156 & 120 & 30 & 10 & 220 & 52 & 52 \\
\hline 14 & 936 & 720 & 30 & 15 & 717 & 672 & 312 \\
\hline 15 & 1092 & 840 & 30 & 18 & 692 & 644 & 644 \\
\hline 16 & 1092 & 840 & 30 & 17 & 691 & 644 & 644 \\
\hline 17 & 780 & 600 & 30 & 18 & 608 & 560 & 560 \\
\hline 18 & 936 & 720 & 30 & 19 & 721 & 672 & 312 \\
\hline 19 & 1092 & 840 & 30 & 19 & 693 & 644 & 644 \\
\hline 20 & 1092 & 840 & 30 & 22 & 696 & 644 & 644 \\
\hline 21 & 468 & 360 & 30 & 33 & 582 & 156 & 156 \\
\hline 22 & 312 & 240 & 30 & 13 & 387 & 104 & 104 \\
\hline 23 & 624 & 480 & 30 & 59 & 537 & 448 & 208 \\
\hline 24 & 468 & 360 & 30 & 13 & 559 & 156 & 156 \\
\hline 25 & 468 & 360 & 30 & 23 & 569 & 156 & 156 \\
\hline 26 & 624 & 480 & 30 & 14 & 492 & 448 & 208 \\
\hline
\end{tabular}

\section{Zavedení elektrické sítě}

Problém s nelegálním odběrem elektřiny se rozhodlo zastupitelstvo řešit prostřednictvím dohody o zavedení legální elektrické sítě v prostoru osady se slovenskou společností pro výrobu a distribuci elektřiny ENEL. Tento proces se odehrál ve dvou následných krocích, které však byly pro obyvatele osady fatální.

V prvním kroku ENEL zavedl do prostoru osady elektrickou sít' tak, aby každá existující rezidenční jednotka měla připojení na legální elektrickou sít', avšak pouze s jedním instalovaným elektroměrem na celou osadu. Ve svém důsledku to znamenalo jeden společný účet s předpokladem, že obyvatelé osady mezi sebou udělají dohodu o tom, kolik kdo zaplatí. Tento postup je srozumitelný v kontextu toho, jak se majoritní členové dívají na obyvatele 
osady. Osada je vnímána jako autonomní politická jednotka. Starosta dlouhodobě odmítal řešit problémy v prostoru osady na individuální úrovni a nutil obyvatele, aby delegovali svého zástupce označovaného jako vajda, se kterým byl ochoten jednat o vzniklých problémech a zároveň na něho delegoval způsoby řešení prípadných problémů.

Pro východní Slovensko není tento pohled na osady jako autonomní, v zásadě samosprávné jednotky neobvyklý. Na jedné straně tím starosta přichází o možnost důkladnější obeznámenosti s realitou sociálních vztahů $\mathrm{v}$ prostoru osady, na straně druhé tím obyvatelé osady získávají určitou nezávislost, která se však ztrácí v jakémkoliv momentě, kdy by mělo dojít $\mathrm{k}$ všeobecnému konsenzu (jako např́klad $\mathrm{v}$ př́ípadě placení společného účtu za elektřinu). Výsledkem diskuzí o placení elektřiny byly vzrůstající konflikty mezi obyvateli osady, které vyvrcholily neplacením účtů za odběr elektřiny a rapidně vzrůstajícím dluhem za neuhrazené faktury.

Na druhou stranu se ukázalo, že konfliktní situace mezi obyvateli osady jsou velice užitečné pro místní samosprávu. Obyvatelé osady se $\mathrm{v}$ hádkách rozdělili do několika skupin a starosta začal v předvolebním období vyjednávat s nejsilnější z nich, která byla pod kontrolou mého domácího, samosprávou i obyvateli osady uznávaným vajdou a pod př́slibem zlepšení životních podmínek $\mathrm{v}$ areálu osady tento vajda pak za využití určité sumy peněz, které obdržel od starosty obce, motivoval obyvatele osady, aby v obecních volbách volili stávajícího starostu.

Bezprostředně po vítězství, které bylo umožněno právě díky hlasům obyvatel osady, začal staronový starosta vyjednávat se společností ENEL o zavedení separátních elektroměrů v areálu osady. Tyto elektroměry však nebyly zavedeny ke každé z existujících rezidenčních jednotek, ale pouze na pět oficiálních čísel popisných, která jsou spojena s pěti syny zakládajícího páru (srov. Obrázek 5). Výsledným efektem je, že elektrická sít’ s pěti elektroměry tvoří

Obrázek 5: Rozvod elektrické sítě a její korespondence s descendenčními skupinami

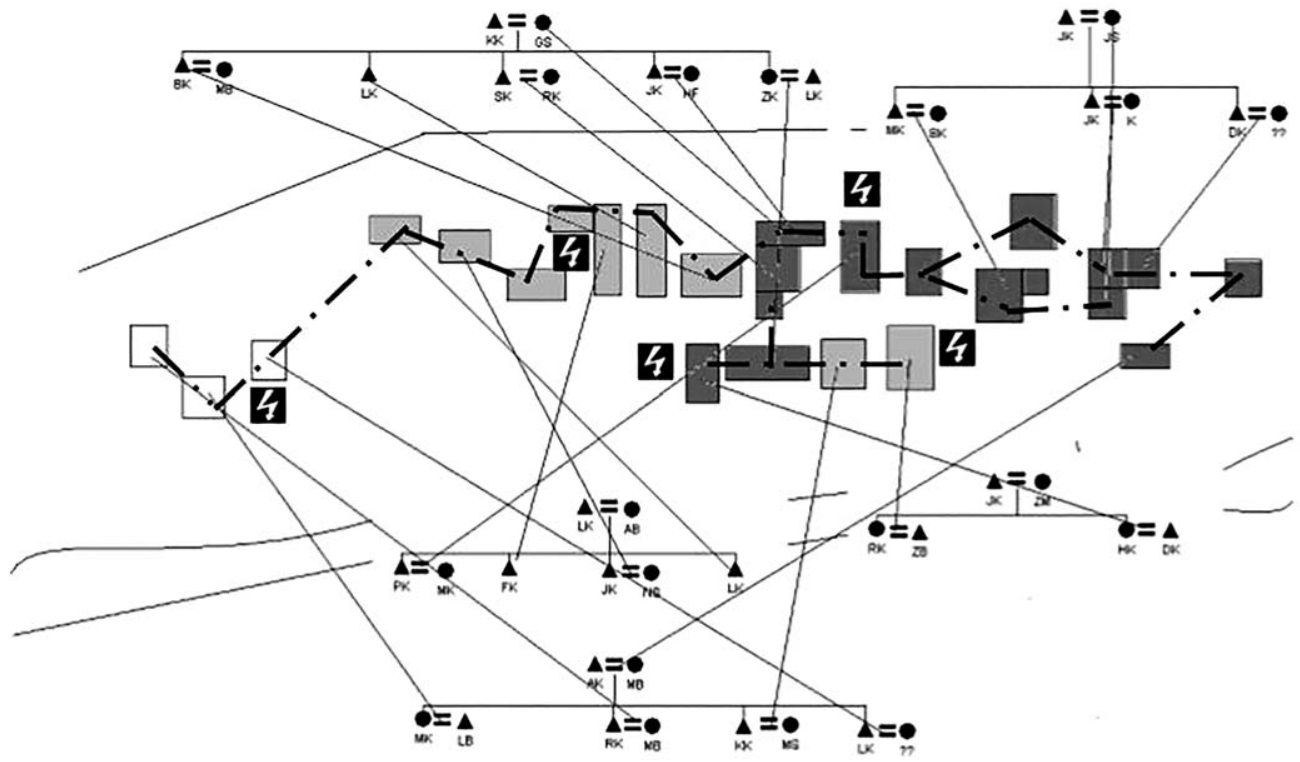


paralelní systém k místní formě kognatické descendence (fajtě), kterou lze jednoduše popsat jako vztahovou soustavu, v rámci které, kdo žije a platí společný účet za elektřinu pod př́slušným popisným číslem, referuje $\mathrm{k}$ jednomu z pěti synů zakladatelského páru.

V tomto smyslu zavedení elektrické sítě zhoršilo místní vztahy. Zatímco v období bez elektřiny se většina lokálních konfliktủ řešila na individuální úrovni, v období po zavedení elektřiny začaly konflikty nabývat kolektivní povahy. Dohoda o způsobu placení společných účtů za elektřinu se netýkala jednotlivců, ale všech, kdo byli ve vztahu $\mathrm{k}$ jednomu z pěti elektroměrů. Zavedení elektrické sítě v areálu osady je tak možné rozumět jako infrastrukturnímu spojení, ze kterého se však v kontextu nekončících hádek o placení účtu za elektřinu stala forma rozpojení. $\mathrm{K}$ podobnému rozpojení došlo mezi obyvateli osady a rezidenty majoritní obce. Všichni jsou napojeni na stejnou elektrickou sít', na druhou stranu díky zavedení elektřiny do areálu osady došlo k zvětšení rozdílu mezi nimi, především díky prohlubujícímu se zadlužení a vzrůstající chudobě obyvatel osady. To, co bylo na osadě spíše výjimkou - půjčování peněz od lichváře -, se stalo pravidlem a zadlužení obyvatel osady se stalo reálným problémem podmíněným stálou závislostí na lichvárích. Lidé sice získali v důsledku zavedení elektrriny do prostoru osady efektivní kontrolu na svým zdravím a zdravím svých dětí, na druhou stranu začaly být enormním způsobem zatěžovány jejich rodinné rozpočty. Televize, satelity, mobilní telefony, ale i ledničky a mrazáky byly pravidelně zastavovány a opětovně vykupovány. ${ }^{7}$ A tak to, co bylo vnímáno jako zdroj a symbol určitého zkvalitnění života, stalo se dočasným a velmi nejistým.

\section{Infrastruktura a lokální politika}

Jakákoliv zástava zejména televizorů a satelitů (či v nejhorším případě odpojení od elektřiny a následné vytváření černého odběru) naznačuje, jak dochází k opakovaným přerušením, kdy je ve hře ztráta kontroly nejen nad svým zdravím, ale obecně nad svým lidstvím. Pokud mají vznik osady a zavedení veřejného vodovodu, veřejného osvětlení a elektrické sítě něco společného, je to důraz na kontrolu. Mít kontrolu nad nově príchozími členy fajty v každém afinním vztahu je stejně důležité jako mít pod kontrolou své zdraví nebo svého nového souseda či nového starostu.

Když jsem se ptal Laca, proč se tak aktivně zasazuje za opakovanou volbu starosty a korumpuje jeho penězi zbytek obyvatel osady, vysvětlil mně, že tento starosta je pro něho akceptovatelný. Podle něj je díky korupcím a problematickým postupům obce, které byly pro Laca spojené především $\mathrm{s}$ výstavbou veřejného vodovodu a veřejného osvětlení, předvídatelný a vydíratelný. Nad jakýmkoliv novým starostou by Laco neměl takovou kontrolu a jako vajda by ztratil účinný nástroj, jak zlepšit životní podmínky v romské osadě.

$\mathrm{Na}$ úrovni majoritní obce však situace nebyla o nic lepší. Myšlenka na přesídlení obyvatel z romské osady do jiné lokality byla př́iležitostně oživována a zavedení elektrické sítě a veřejného osvětlení bylo a je odpůrci využíváno proti možnému přesídlení spojenému vždy s argumentem neúčelnosti financování výstavby veřejného vodovodu, veřejného elektrického

7 Podobně jako zdraví, tak i lichva je velmi komplexní fenomén, v němž je vztah podmíněný členstvím v určité descendenční skupině nahrazován vztahem vymezeným na základě dluhu. Pro bližší pochopení této souvislosti viz Scheffel (2010) nebo Hrustič (2015a, b). 
osvětlení a elektrické sítě v prostoru osady. Jedním z důsledků zavedení infrastrukturního vybavení do prostoru osady je pro odpůrce stvrzení její lokace. Zastánci přesídlení upozorňovali na dlouhodobou neudržitelnost především ve vztahu $\mathrm{k}$ růstu počtu obyvatel osady. Jejich argument spočíval v rostoucím riziku nelegální výstavby na soukromých pozemcích. Spor vyústil $\mathrm{v}$ roce $2010 \mathrm{v}$ neschopnost nalézt vhodného kandidáta na starostu v dalším volebním období a část obyvatel začala podporovat nápad, že by starostu $\mathrm{v}$ jejich obci mohl vykonávat velice úspěšný starosta ze sousední obce. Zbývající dva kandidáti si uvědomili, že volby vyhrají jen za pomocí obyvatel osady, a začali hledat možné cesty, jak si je dostat na svou stranu. V podstatě uplatnili stejnou strategii jako předešlý starosta $\mathrm{s}$ tím, že každý $\mathrm{z}$ kandidátů začal cílit na jinou autoritu. První z nich tradičně oslovil Laca. Druhý z nich se zaměřil na jeho bratra.

Stejně jako byla vyhrocená předvolební kampaň na úrovni majority, podobně agresivní byla $\mathrm{v}$ rámci osady. Lidé $\mathrm{v}$ osadě se rozdělili podle míry loajality $\mathrm{k}$ těmto bratrům. Lacův bratr peníze určené $\mathrm{k}$ získání hlasů pro př́slušného kandidáta nakonec využil jako způsob, jak se dostat mezi lichváře. Zatímco Laco peníze používal jako dar nebo jednorázovou platbu za volební hlas, jeho bratr je využíval jako půjčky na vysoký úrok, které vedly k prohloubení zadluženosti jeho klientů, končící neschopností pravidelně platit za elektřinu, a ohrožující tak zdraví členů descendenční skupiny neplatičů. Volby nakonec vyhrál kandidát s kompromisním návrhem slibujícím výstavbu bytů nízkého standardu v prostoru osady, který začali obyvatelé osady podporovat a na který dostal obecní úrad v roce 2014 dotaci od slovenské vlády ve výši 3000 eur na vypracování studie proveditelnosti.

V místním mikroreginu má však obec a její majoritní obyvatelé pochybný status. Nahlíží se na ni nikoliv jen jako na obec s problematickou romskou komunitou, ale také jako na obec, která je neschopná dosáhnout funkčního konsensu nejen v řešení problémů spojených s romskou osadou či s volbou starosty, ale také takových projektů, jako je územní plán obce, který je nezbytným předpokladem pro další výstavbu a systematický rozvoj obce. ${ }^{8}$ Díky tomu obec a lidé v ní žijící získávají status zaostalé obce a majoritní obyvatelé okolních obcí nahližźi na majoritu popisované obce obdobně, jako oni nahlíží na obyvatele místní romské osady. I když by se dalo nesystematické zavádění infrastrukturního vybavení do prostoru osady vysvětlovat jako strategie, jak dosáhnout kontroly nad chováním a počtem jejích obyvatel, ve snaze uchovat si určitou morální, kulturní, etnickou či civilizační homogenitu, integritu a nadřazenost, popisovaná obec je dobrým př́kladem toho, že takováto (jakkoliv propracovaná) kontrola je spojena s rizikem stávání se těmi druhými, méně lidskými, čím dál podobnějšími těm, jimiž tito nadřazení opovrhují.

\section{Závěr}

Podle Ismaela Vacara, Kristy Harper a Setha Murray (Vaccaro et al. 2015) formy přerušení (disconnection) je možné dát do souvislosti s industrializací a deindustrializací a s tím, jak se tyto procesy podílejí na konceptualizaci přírody či krajiny, jakou s nimi mají lidé zkušenost a jak vymezují

8 Obec přijala územní plán až v roce 2014. Ve srovnání s okolními obcemi je to pozdě. Sousední obec, která je v publikaci A. Mušinky (2012) Podarilo sa popisována jako dobrý př́klad řešení problémů spojených s existencí romské komunity, přijala územní plán již v roce 1986 a aktualizovaný byl v roce 2007. 
jejich zkušenost s postindustriálním prostorem a časem. Tento text se oproti tomu snažil upozornit na způsoby přerušení, které vznikají v kontextu zavádění základní infrastruktury do prostoru osady, na to, jak je infrastrukturní sít provázána s dalšími formami vědění či praxe a jak se podílí na utváření rozdílů mezi těmi, kteří žijí v prostoru osady, a majoritní obcí. Infrastrukturní implementace v tomto smyslu není neproblematická, ale je výsledkem vyjednávání a politických strategií sledujících vynucení svého zájmu na úrovni obecního úruadu jak ze strany obyvatel osady, tak majority.

V tomto smyslu se přerušení podmíněná různými formami infrastrukturního spojení podílejí na utváření rozdílů mezi rozvinutými a zaostalými. Zatímco rozvinutí mají možnost plně participovat na naplňování lidskosti, zaostalí jsou s každým dalším infrastrukturním propojením vystaveni riziku ztráty lidství. Infrastruktura se stává měřítkem způsobů spojení a rozpojení podílejících se na vymezení či zpochybnění humanity obyvatel romské osady. Na jedné straně došlo $\mathrm{k}$ vysídlení zakladatelského páru do areálu sloužícího v minulosti jako hřbitov uhynulých hospodářských zviŕat. Výsledkem je anonymizace obyvatel osady přispívající k jejímu vnímání na straně majority jako autonomní samosprávné jednotky reprezentované místním vajdou. Zatímco zakladatelský pár byl ještě majoritou kategorizován termínem „naši Romové/Cigáni“, jejich potomci jsou již vnímaní jako cizí. Samotní obyvatelé lokální sociální vztahy obvykle popisují souslovím fajta, která v tomto smyslu vystupuje jako komplexní forma spř́izněností (relatedness) vázaných na pět descendenčních skupin referujících k pěti synům zakladatelského páru. Tyto descendenční skupiny jsou provázány s pěti oficiálními popisnými čísly, na které jsou připojeny měřiče spotřeby elektrického proudu. Fajta tak nutně nemusí být orientována podle prokreace či participace na určitém způsobu života obyvatel osady, ale na základě sdílení elektroměru, ze kterého se však v jakémkoliv př́ípadě neschopnosti platit za elektřinu stává výrazný dezintegrační prvek těchto descendenčních skupin.

Žít na místě bývalého hřbitova hospodářských zviřat je pocit’ováno obyvateli osady jako nedůstojné, stejně jako pít vodu z místního veřejného vodovodu. Ten není prodlouženým veřejným vodovodem $\mathrm{v}$ obci, ale paralelním rozvodem svádějícím vodu z problematického rezervoáru původně určeného jako zásobárna vody pro dobytek v místním, dnes již neexistujícím, zemědělském družstvu. Paralelní vodovod je tak další formou rozpojení zpochybňujícího lidskost obyvatel osady. Pro ně je tento vodovod jen potvrzením toho, že majorita jim nerozumí jako lidským bytostem, ale spíše jako ne-lidem, zviŕatům, pro něž není vhodné či je zbytečné plnohodnotné napojení na veřejný vodovod. Zároveň díky nemožnosti účinně kontrolovat zdroj vody pro jeho nedostatečné zakrytí je konzumace vody z tohoto vodovodu spojená s vysokým zdravotním rizikem. Paradoxně byl tento problém vyřešen zavedením elektrického osvětlení, které vytvořilo možnost černého odběru. Díky němu mezi obyvateli osady získala na významu rychlovarná konvice, která umožnila účinně a rychle převařovat vodu z problematického veřejného vodovodu. Stejně tak významná se stala žárovka využívaná jako preventivní nástroj proti nechtěným a velmi obávaným návštěvám mulu jak v domácnostech, tak prostoru osady. Po zavedení veřejného osvětlení lidé v osadě vnímali svůj život jako mnohem zdravější. Majorita však díky nesouvislému veřejnému osvětlení v prostoru mezi obcí a osadou získala efektivní nástroj na udržování osady v jejích stávajících hranicích. Každý z osady preferuje výstavbu rezidenční jednotky spíše $\mathrm{v}$ místě, které je v dosahu veřejného osvětlení. Na druhou stranu se zavedením veřejného osvětlení vytvořila možnost černého odběru a nárůstu ekonomické náročnosti provozu veřejného osvětlení obecního 
úřadu. Obyvatelé osady tím vytvářeli nátlak na místní obecní zastupitelstvo a starostu obce usilující o zavedení elektrické sítě v prostoru osady. Z elektrické sítě se stalo politikum, které ve svém důsledku vedlo $\mathrm{k}$ prohlubujícímu zadlužení obyvatel osady a dezintegraci jejich lokální komunity (fajty). Elektrická sít’ se tak stala jedním z důležitých prostředků rozpojování. K podobné dezintegraci došlo na úrovni majority, která se rozdělila na dva tábory. První z nich prosazoval změnu lokace osady na vhodnější místo s vyhovujícím a funkčním infrastrukturním zázemím, druhý naopak prosazoval jen udržování současného stavu. Spor vyvrcholil neschopností nalézt $\mathrm{v}$ obci vhodného kandidáta na starostu. Zvítězil kompromisní, ale také velmi kontroverzní návrh plánující výstavbu bytů nízkého standardu v areálu osady, tedy prostoru, který je vzhledem k počtu obyvatel velice problematický a představující pro budoucí již tak napjaté vztahy mezi obyvateli osady a místní majoritu závažné riziko. Nesystematičnost výstavby se může stát jen další formou rozpojení udržující obyvatele osady $\mathrm{v}$ její problematické lokaci a přispívající tak $\mathrm{k}$ jejich prohlubujícímu se pocitu méněcennosti, zaostalosti a frustrace. Souvislost mezi jednotlivými měřítky, činnostmi a konkrétními formami spojení a rozpojení je pro lepší srozumitelnost vynesena v přehledové tabulce.

Tabulka 2: Přehled souvislostí mezi měřítky, činnostmi a formami spojení/rozpojení

\begin{tabular}{|c|c|c|c|}
\hline MĚŘÍTKO & ČINNOST & SPOJENÍ & ROZPOJENÍ \\
\hline PROSTOR A ČAS & $\begin{array}{l}\text { Vysídlení } \\
\text { zakladatelského } \\
\text { páru do areálu } \\
\text { osady }\end{array}$ & $\begin{array}{l}\text { Formování zpưsobů } \\
\text { sprízněnosti vázané na pět } \\
\text { descendenčních skupin, } \\
\text { kmotrovské vztahy a systém } \\
\text { partnerských výměn se } \\
\text { sousedními osadami }\end{array}$ & $\begin{array}{l}\text { Přerušení každodenní interakce } \\
\text { mezi místními Romy a majoritou, } \\
\text { anonymizace následných generací, } \\
\text { autonomie romské osady }\end{array}$ \\
\hline DRUHY SPOJENÍ & $\begin{array}{l}\text { Výstavba } \\
\text { vodovodu } \\
\text { Veřejné osvětlení } \\
\text { Elektrická } \\
\text { sít s jedním } \\
\text { elektroměrem } \\
\text { Elektrická sít se } \\
\text { čtyřmi elektroměry }\end{array}$ & $\begin{array}{l}\text { Vodovod je prodloužením } \\
\text { existujícího vodovodu, ze } \\
\text { kterého byla napájená } \\
\text { hospodářská zvîrata } \\
\text { v bývalém zemědělském } \\
\text { družstvu } \\
\text { Rozvod elektrické sítě pro } \\
\text { černý odběr elektřiny } \\
\text { Jeden elektroměr nutící } \\
\text { k všeobecnému konsenzu } \\
\text { Čtyři elektroměry nutící ke } \\
\text { konsenzu na úrovni čtyř } \\
\text { descendenčních skupin }\end{array}$ & $\begin{array}{l}\text { Vodovod není napojen na existující } \\
\text { veřejný vodovod v majoritní obci } \\
\text { Vytvoření neosvětleného prostoru } \\
\text { přispělo k vymezení hranice prostoru } \\
\text { osady } \\
\text { Jeden elektroměr generuje } \\
\text { neschopnost placení účtů za } \\
\text { elektřinu vedoucí ke konfliktům mezi } \\
\text { obyvateli osady a jejich prohlubující } \\
\text { se chudobě } \\
\text { Destabilizace descendenčních } \\
\text { skupin a sousedství spojená s rizikem } \\
\text { konfliktu a následné neschopnosti } \\
\text { platit účet za elektřinu }\end{array}$ \\
\hline $\begin{array}{l}\text { MATERIALITA } \\
\text { A VĚDĚNí }\end{array}$ & $\begin{array}{l}\text { rychlovarná } \\
\text { konvice } \\
\text { žárovka }\end{array}$ & $\begin{array}{l}\text { Ochrana před důsledky } \\
\text { kontaktu se závadnou vodou } \\
\text { Ochrana před důsledky } \\
\text { kontaktu s muly }\end{array}$ & $\begin{array}{l}\text { Přerušení spojení s nečistým zdrojem } \\
\text { vody } \\
\text { Přerušení spojení se světem mulů }\end{array}$ \\
\hline $\begin{array}{l}\text { INFRASTRUKTURA } \\
\text { A LOKÁLNÍ } \\
\text { POLITIKA }\end{array}$ & $\begin{array}{l}\text { Černý odběr } \\
\text { elektřiny } \\
\text { Sporný sazebník } \\
\text { Elektrická } \\
\text { sít s jedním } \\
\text { elektroměrem } \\
\text { Elektrická sít se } \\
\text { čtyřmi elektroměry }\end{array}$ & $\begin{array}{l}\text { Konsenzus ve snaze uchovat si } \\
\text { kontrolu nad zdravým životem } \\
\text { osadě } \\
\text { Společná dohoda mezi } \\
\text { starostou a obyvateli osady }\end{array}$ & $\begin{array}{l}\text { Zvýšení ekonomické zátěže obce } \\
\text { Rozdělená majorita a rozdělené } \\
\text { obyvatelstvo osady, které je } \\
\text { postiženo zvyšujícím se dluhem } \\
\text { z neschopnosti splácet účty } \\
\text { za elektřinu }\end{array}$ \\
\hline
\end{tabular}




\section{Literatura}

BELÁK, Andrej. 2015a. „Segregovaní Rómovia a zdravotné politiky: etické a praktické rozpory“. Pp. 172-207 in Tatiana PODOLINSKÁ a Tomáš HRUSTIČ (eds.). Čierno-biele svety. Rómovia v majoritnej spoločnosti na Slovensku. Bratislava: Veda a Ústav etnológie SAV.

BELÁK, Andrej. 2015b. Medicína v segregovanej rómskej osade. Príklad z juhu stredného Slovenska. Romano Džaniben 22(1): 57-84.

BIJKER, Wiebe E., Thomas P. HUGHES, Trevor PINCH a Deborah G. DOUGLAS. 1987. The Social Construction of Technological Systems: New Directions in the Sociology and History of Technology. Cambridge: MIT Press.

BOWKER, Geoffrey C. a Susan Leigh STAR. 1999. Sorting Things out: Classification and Its Consequences. Cambridge: MIT Press.

DELEUZE, Gilles a Félix GUATTARI. 2010. Tisic plošin. Praha: Hermann \& synové.

DOBRUSKÁ, Petra. 2008. „Víra v revenanty jako součást náboženství bystranských Romů.“ Romano Džaniben 2: 7-27.

DOUGLAS, Mary. 1970. Purity and Danger: An Analysis of Concept of Pollution and Taboo. Harmondsworth: Penguin.

EDWARDS, Paul N., Geoffrey C. BOWKER, Steven J. JACKSON a Robin WILLIAMS. 2009. „Introduction: An Agenda for Infrastructure Studies.“ Journal of the Association for Information Systems 10(5): 6.

FERGUSON, James. 1999. Expectations of Modernity: Myths and Meanings of Urban Life on the Zambian Copperbelt. Berkeley: University of California Press.

FILČÁK, Richard. 2012. „Environmental Justice and the Roma Settlements of Eastern Slovakia: Entitlements, Land and the Environmental Risks.“ Sociologický Časopis/Czech Sociological Review 48(3): 537-562.

GODELIER, Maurice. 2011. The Metamorphoses of Kinship. London: Verso.

HARAWAY, Donna. 2008. When Species Meet. Minneapolis: University of Minnesota Press.

HARVEY, Penny a Hannah KNOX. 2012. The Enchantments of Infrastructure. Mobilities 7(4): 521-536.

HRUSTIČ, Tomáš. 2015a. „Usury among the Slovak Roma: Notes on Relations between Lenders and Borrowers in a Segregated Taboris“. Pp. 31-48 in Micol BRAZZABENI, Manuela I. CUNHA a Martin FOTTA (eds.). Gypsy Economy - Romani Livelihoods and Notions of Worth in the 21st Century. New York: Berghahn.

HRUSTIČ, Tomáš. 2015b. „Emické vnímanie úžery v segregovaných rómskych osadách na východnom Slovensku“. Pp. 208-223 in Tatiana PODOLINSKÁ a Tomáš HRUSTIČ (eds.). Čierno-biele svety. Rómovia v majoritnej spoločnosti na Slovensku. Bratislava: Veda a Ústav etnológie SAV.

HÜBSCHMANNOVÁ, Milena 2005. „Viera v mula u slovenských Rómov.“ Slovenský národopis 53(2): $172-186$.

JENSEN, Casper Bruun a Atsuro MORITA. 2015. „Infrastructures as Ontological Experiments.“ Ethnos 1: $1-12$.

KOBES, Tomáš. 2010. „Fajta a povaha prŕbuzenství obyvatel východoslovenských romských osad.“ Sociologický časopis/Czech Sociological Review 46(2): 235-255.

LARKIN, Brian. 2013. „The Politics and Poetics of Infrastructure.“ Annual Review of Anthropology 42: 327-343.

MILLER, Daniel. 2005. „Materiality. An Introduction.” Pp. 1-50 in Daniel MILLER (ed.). Materiality. Durham: Duke University Press.

MUŠINKA, Alexander. 2012. Podarilo sa. Prikklady úspešných aktivit na úrovni samospráv smerujúcich k zlepšeniu situácie Rómov. Prešov: Vydavatel'stvo Prešovskej univerzity v Prešove. 
MUŠINKA, Alexander, Daniel ŠKOBLA, Jakob HURRLE, Kvetoslava MATLOVIČOVÁ a Jaroslav KLING. 2014. Atlas rómskych komunit na Slovensku 2013. Bratislava: Regionálne centrum Rozvojového programu OSN Pre Európu a Spoločenstvo nezávislỳch štátov v Bratislave.

SKUPNIK, Jaroslav. 2010. Antropologie př́buzenství. Přibuzenství, manželství a rodina v kulturně antropologické perspektivě. Praha: Sociologické nakladatelství.

Správa o životnỳch podmienkach rómskych domácností na slovensku. 2010. Bratislava: Regionálne centrum Rozvojového programu OSN pre Európu a Spoločenstvo nezávislých štátov v Bratislave. Cit. 16. června 2015 (https://www.employment.gov.sk/files/undp-sprava-2010_na-web.pdf).

STAR, Susan Leigh. 1999. „The Ethnography of Infrastructure.“ American Behavioral Scientist 43(3): 377-391.

STRATHERN, Marilyn. 1995. The Relation. Issues in Complexity and Scale. Cambridge: Prickly Pear Press.

ŠKOBLA, Daniel a Richard FILČÁK. 2014. „Bariéry v prístupe k pitnej vode ako aspekt sociálneho vylúčenia rómskej populácie." Sociológia - Slovak Sociological Review 46(5): 620-637.

VACCARO, Ismael, Krista HARPER a Seth MURRAY. 2015. „The Anthropology of Postindustrialism: Ethnographies of Disconnection.” Pp. 1-21 in Ismael VACCARO, Krista HARPER a Seth MURRAY (eds.). The Anthropology of Postindustrialism: Ethnographies of Disconnection. New York: Routledge.

\section{Autor}

Tomáš Kobes působí jako odborný asistent na Katedře sociologie Filozofické fakulty Západočeské univerzity v Plzni. Ve své práci se zabývá teorií příbuzenství, romskou problematikou a sociální exkluzí.

Kontakt: kobes@kss.zcu.cz 